\title{
小型分散式免震部材を用いた戸 RESEARCH AND DEVELOPMENT OF 建て住宅免震工法の開発 SEISMIC ISOLATION SYSTEM FOR RESIDENCE BY SIMPLE STRUCTURE BEARING AND DAMPER
}

\section{深澤協三——1＼cjkstart松本達治 一 \\ 京島弘之一 $* 3$ 米倉正剛 $-* 3$ \\ 立花正彦 — $* 4$ \\ キーワード \\ 免震，住宅，転がり支承，高減衰ゴム，加力実験，施工実験}

Keywords :

Base isolation, Residence, Bearing, Damper, Loading test, Execution test

\author{
Kyozo Fukazawa - $* 1$ \\ Hiroyuki Kyoujima $-* 3$ \\ Masahiko Tachibana $-* 4$
}

This paper presents that development of a cost-effective method of seismic isolation system for residence. This perticular construction method makes use of seismic isolators with compact and simple bearing and damping materials. With an RC structured base isolation story, the entire construction method, including installation of the seismic isolator, was possible using conventional construction techniques.

Development of this construction method required construction and structural experiments. Results from construction experiments proved that the method developed is satisfactory in producing the base isolation story, while structural testing proved that there is positive capacity for vertical loads in the base isolation story, and that satisfactory earthquake protection was present

\section{2. 免震工法概要}

1.はじめに

ここ数年、人的な被害を伴う規模の大きな地震が頻発している。 築年数の新しい戸建て住宅では建物倒壊・大破に至る例は少ない一 方、住宅内の家具・什器の転倒等によってケガをする例が増えてい る。また、ケガに至らなくとも割れたガラス・散乱した荷物等によ り、震災後住宅としての機能を果たせず、例えば避難所生活を余儀 なくされる場合もある。

このような「震災」に対する対策として「免震構造」は非常に有 効である。戸建て住宅の免震化は、個人の生命・財産を守るだけで はなく、震災後の地域全体の避難・復旧への負担を低減する役目も 果たしており、社会的急務といっても過言ではない。

しかし、現状では上記の通り様々なメリットをもたらす「免震構 造」が、戸建て住宅に普及しているとは言い難い。普及を阻む大き な理由として「コスト」面でのデメリットが大きいと言われている。 そこで、戸建て免震の大幅なコストダウンを目標に、簡単な構造か ら成り、かつ廉価な免震部材を開発した。さらに、この免震部材に 適合した免震層部分の施工方法も併せて開発した。開発に際しては 免震部材の力学的特性把握のための加力実験、施工方法・施工精度 確認のため施工実験、施工実験で構築した免震層を対象に上部建物 重量による免震層 RC 造スラブ及び転がり支承の変形性状の確認、 地震時の転がり支承・減衰材の変形性状、接合部応力伝達の確認の ための構造実験（静的な鉛直・水平載荷実験）を行った。

本報は、本免震工法の概要及び上記の各実験結果について報告す るものである。

*1 侏)日本建設業経営協会中央技術研究所工博

( (104-0032 中央区八丁堀2-5-1東京建設会館 3 階)

*2 SRIハイブリッド俐 工博

*3 共立建設湖

*4*東京電機大学工学部建築学科 教授・工博

本免震工法は、免震部材には図 1 に示す「転がり支承」十「減衰 材・復元材 (高減衰ゴム、以下「減衰材」と略称)」を用い、これら 免震部材上に図 2 に示すように RC 造スラブを設ける方式である。 低コストを追求しながらも、RC 造スラブ方式とした理由は、1)重 量を大きくしてトリガー荷重(減衰材降伏前の初期剛性の範囲とな る荷重)を確保し、さらに建物全体を低重心化することにより風・地 震荷重に対する安定性を高める。2)架台部分の耐久性の確保とメン
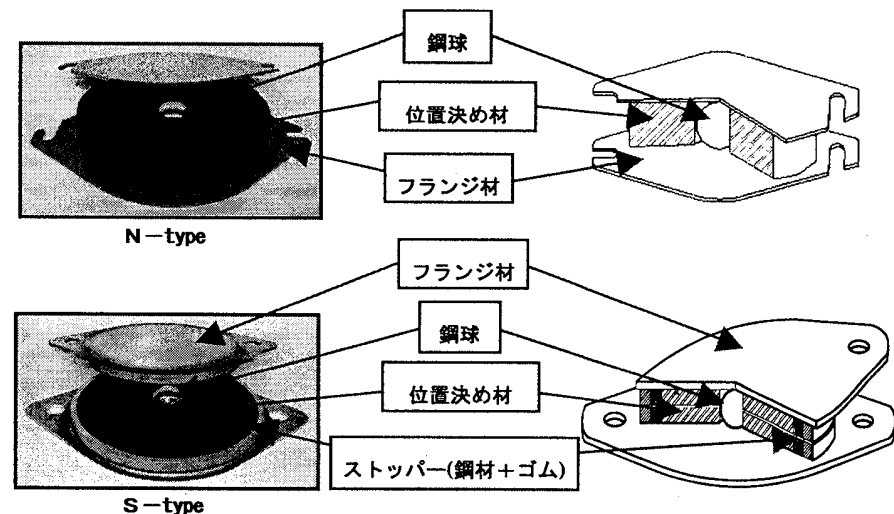

s-type

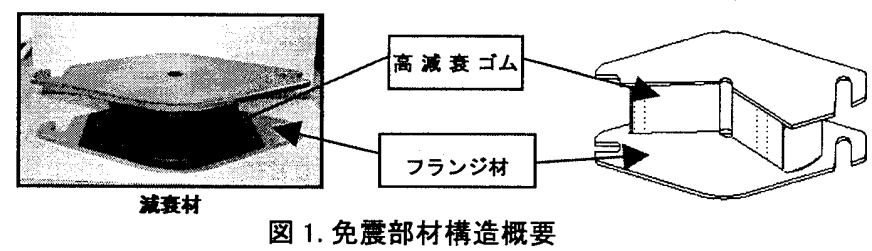

图 1. 免震部材構造概要

*2 SRI Hybrid CO., LTD., Dr. Eng.

*3 KYORITSU Construction CO., LTD.

*4 Prof., Dept. of Architecture, Faculty of Eng., Tokyo Denki Univ., Dr. Eng. 
テナンスフリー化、3)間取りの変更（=柱・壁位置の変更）への 適応性確保（設計時及び将来の増改築）、によるものである。

本工法で用いる免震部材及び施工方法の概要を以下に示す。 (1)兔震部材：転がり支承は、鋼球(ベアリング等に用いる規格品) に高硬度ステンレス板(材質：SUS304、硬度 HRC25 以上)を上下 に配した極めて単純な構造である(なお、鋼球の廻りにはダストカ バー兼輸送・施工中鋼球のずれ留めのためのスポンジ材が取り付 く)。この転がり支承は 2 タイプから成り、1つは設計で想定する 以上の水平変形に対してストッパー機能を持たせるために、上下 フランジ材に円筒形のステンレス材を溶接したタイプ（以下 $\mathrm{S} タ$

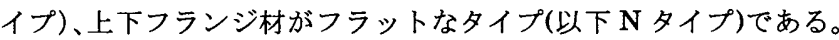
$\mathrm{S}$ タイプは主に建物四隅に配置することとしている。両タイプと も簡便に製造が可能で、コストダウンが図られている。なお、こ れら転がり支承の最大支持荷重は長期 $29.4 \mathrm{kN}$ 、短期 $58.8 \mathrm{kN}$ であ り、上載荷重の多寡に応じて転がり支承を多数個分散して配置す る方式を採っている。

減衰材は円筒形の高減衰ゴムの上下にステンレス板(材質： SUS304)を加硫接着し、高減衰ゴム外周を被覆ゴムにて保護する 簡単な構造である(被覆ゴム込みの直径 $108.5 \mathrm{~mm}$ 、高減衰ゴム高 さ $\mathrm{H}=40,60,80 \mathrm{~mm}$ の 3 タイプ)。減衰材の水平限界変形は $170 \mathrm{~mm}(\mathrm{H}=40 \mathrm{~mm}), 240 \mathrm{~mm}(\mathrm{H}=60 \mathrm{~mm}), 320 \mathrm{~mm}(\mathrm{H}=80 \mathrm{~mm})$ である。 $\mathrm{H}=40 \mathrm{~mm}$ タイプでは限界変形が $170 \mathrm{~mm}$ と小さいが、本免震工法 では極めて稀な地震動に対してはストッパー(S タイプ転がり支 承)による変形制限を前提としている。

(2)施工方法：施工手順は図 2 に示す通りである。転がり支承は写 真 1 に示すように、上下 2 枚亜鉛メッキ鋼板 PL4.5mm（以下取 付プレート）に固定されて基礎面に据え付けられる。この上下の 取付プレートは、コ字形の金物（以下固定金物。PL3.2mm をプ レス加工）により固定されている。固定金物は転がり支承の上下 フランジ材間の平行度を保つ役目と、施工荷重（主にスラブロン クリート打設時の荷重）を支持する役目を担う。また、基礎と免 震部材の接合は、基礎施工時にアンカーボルトを打ち込む方法と 後施エアンカーボルトによる方法の両方が可能である。なお、減 衰材は写真 2 に示すように施工省力化のため上下取付プレート
(PL4.5mm) 介して 2 個 1 組にまとめて配置する（但し、減衰材 には施工荷重を負担させない)。続いて、転がり支承、減衰材上部 に束柱（免震層にメンテナンス及び配管のために最低限必要なク リアランス・約 $40 \mathrm{~cm}$ を確保するために高さ確保のため束柱を設 ける）のコンクリートを打設する。強度発現後に床板型枠に用い る捨て型枠(デッキプレート)敷設用のアングル材を束柱間に掛け 渡す。各通りにデッキプレート敷設した後は通常の方法で床板を 施工する。なお、上部建物に必要なアンカーボルト類も床板コン クリート打設時に打ち込む。以降の上部建物の施工は通常の方法 による。さらに、上部建物施工後(䇋工直前)に、各転がり支承に 取り付けた固定金物を撤去して施工が完了する。

上記の通り、床板型枠にはデッキプレートを用い、さらに施工 荷重を各転がり支承に取り付けた固定金物に支持させることによ り、支保工の設置及び型枠の撤去が不要となった。その結果、免 震層のクリアランスが型枠・支保工からの制限を逃れることが可 能になった(通常 $60 \mathrm{~cm}$ 以上は必要となる。本工法ではメンテナン スに必要な $40 \mathrm{~cm}$ に抑えることが出来る)。さらに、型枠・支保工 の配置・撤去等の施工手間の省力化と同時に狭盒な空間での無理 な型枠・支保工解体作業を無くして施工の安全性を高めている。

\section{3. 免震部材概要}

3. 1 免震部材の仕様

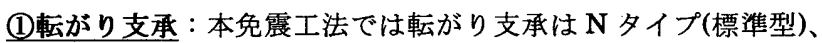
$\mathrm{S}$ タイプ(ストッパー付き)の 2 タイプを用いる。両タイプとも鋼

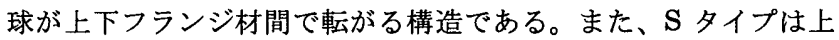
下フランジ外周部にストッパー用円筒形のリングを溶接したもの である。両タイプの形状・寸法及び材質を図 3 に示す。

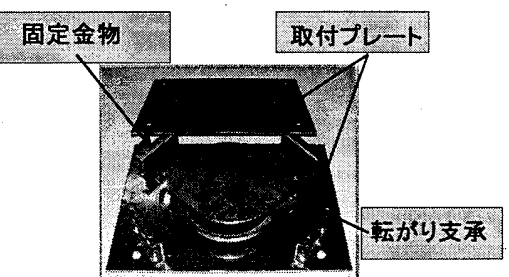

写真 1. 転がり支承

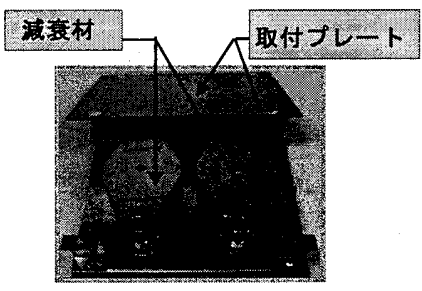

写真 2. 減衰材

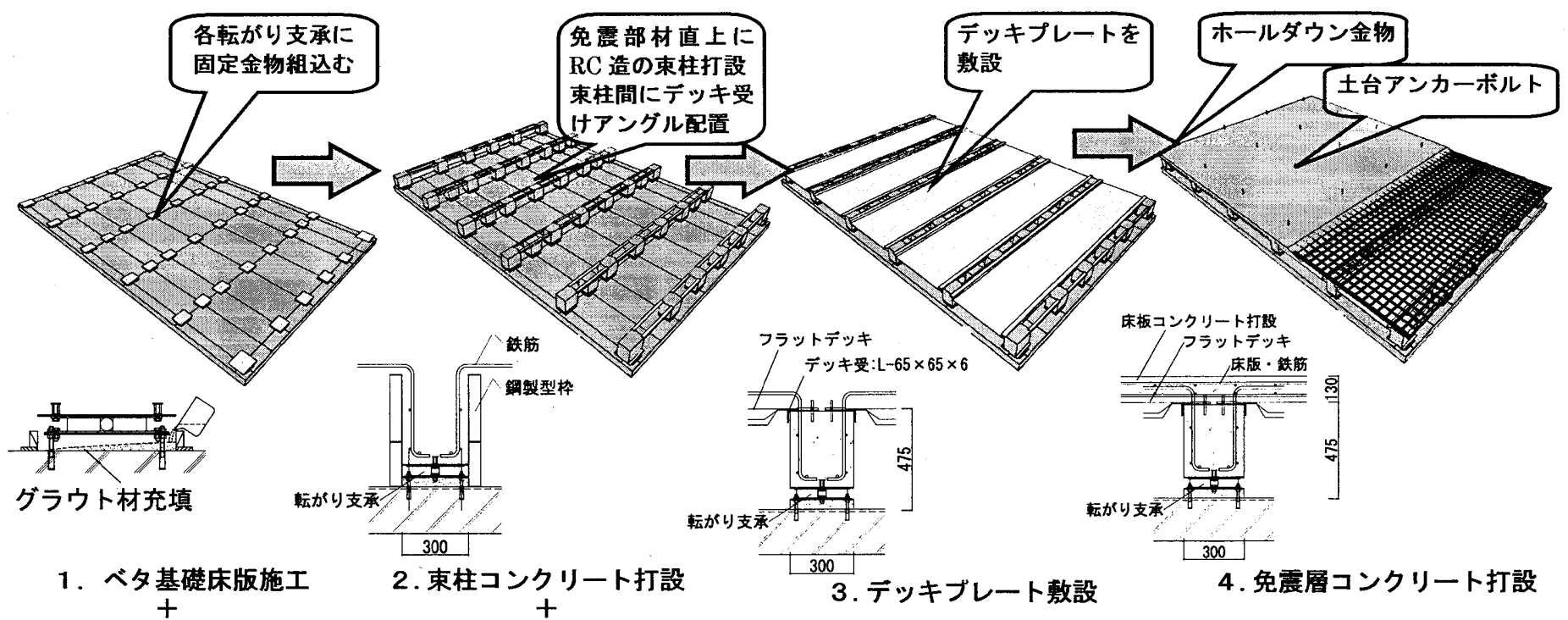

免震部材据え付け

図 2. 施工手順 
(2)减衰材：减衰材は円筒形の高減衰ゴムの上下にステンレス板を 加硫接着し、高減衰ゴム外周を被覆ゴムにて保護する構造である。 減衰材の形状・寸法及び材質を図 4 に示す。
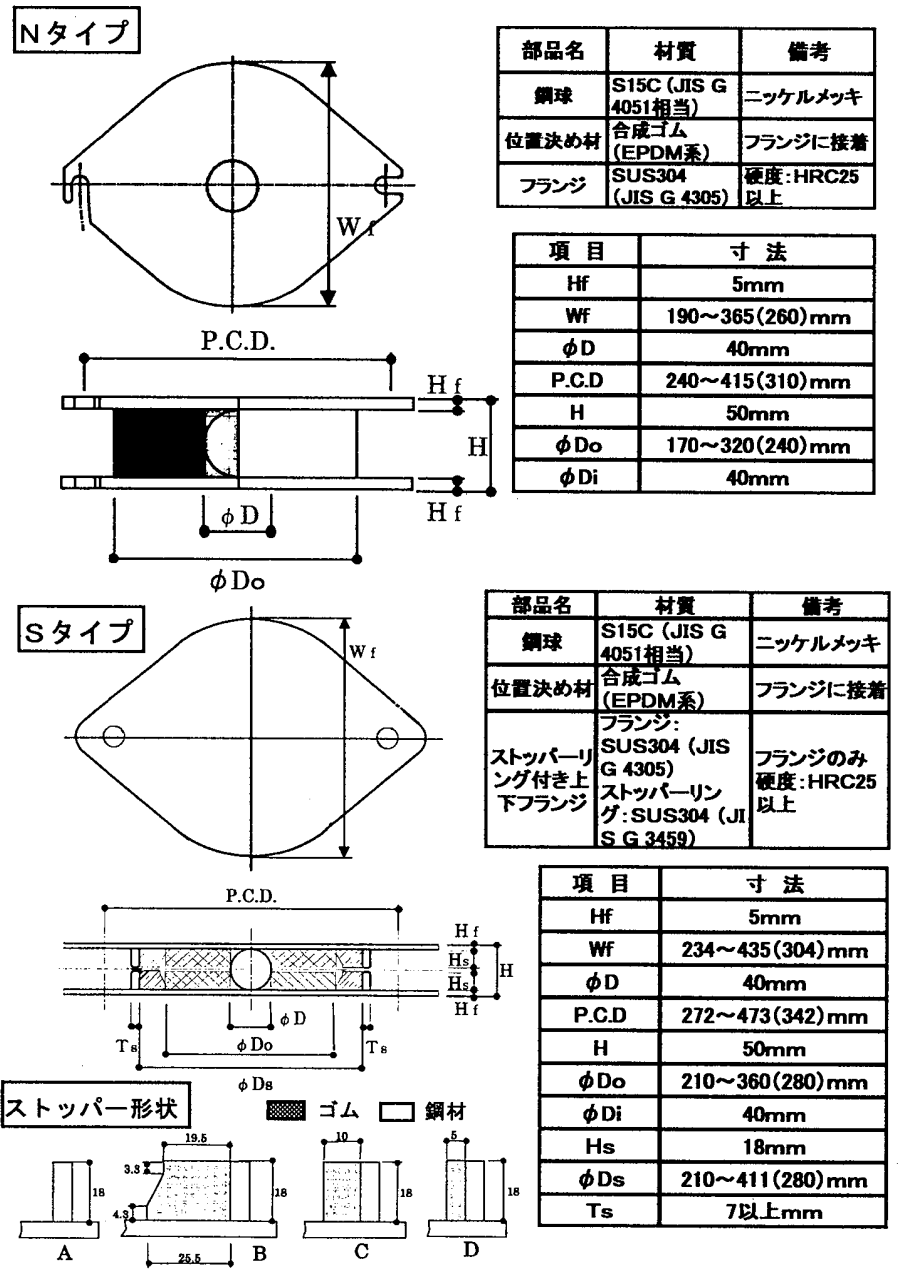

\begin{tabular}{|c|c|}
\hline 項 目 & 寸 法 \\
\hline Hf & $5 \mathrm{~mm}$ \\
\hline Wf & $234 \sim 435(304) \mathrm{mm}$ \\
\hline$\phi D$ & $40 \mathrm{~mm}$ \\
\hline P.C.D & $272 \sim 473(342) \mathrm{mm}$ \\
\hline$H$ & $50 \mathrm{~mm}$ \\
\hline$\phi \mathrm{Do}$ & $210 \sim 360(280) \mathrm{mm}$ \\
\hline$\phi \mathrm{Di}$ & $40 \mathrm{~mm}$ \\
\hline $\mathrm{Hs}$ & $18 \mathrm{~mm}$ \\
\hline$\phi \mathrm{Ds}$ & $210 \sim 411(280) \mathrm{mm}$ \\
\hline$T s$ & 7以上 $\mathrm{rmm}$ \\
\hline
\end{tabular}

図 3. 転がり支承形状寸法及び材質
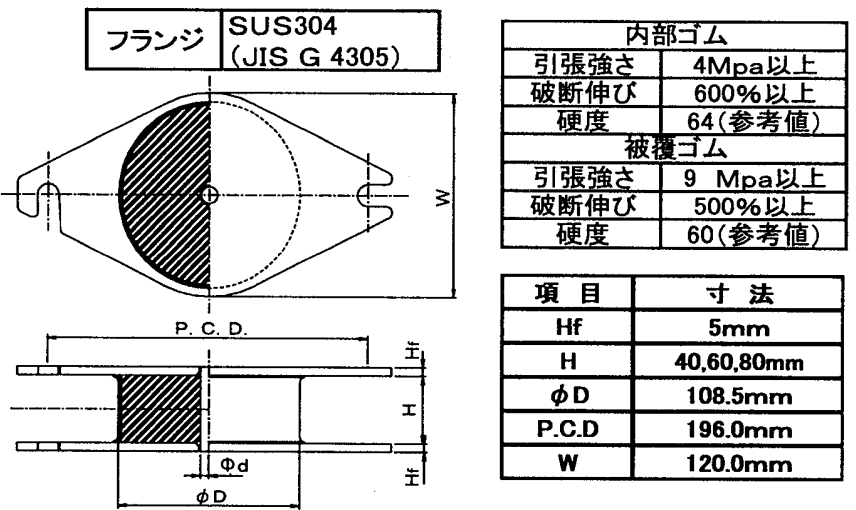

\begin{tabular}{|c|c|}
\hline 項 目 & 寸 法 \\
\hline$H f$ & $5 \mathrm{~mm}$ \\
\hline$H$ & $40,60,80 \mathrm{~mm}$ \\
\hline$\phi D$ & $108.5 \mathrm{~mm}$ \\
\hline P.C.D & $196.0 \mathrm{~mm}$ \\
\hline W & $120.0 \mathrm{~mm}$ \\
\hline
\end{tabular}

\section{2 実験概要}

実験計画を表 1 に示す。転がり支承では「鉛直加力実験」「水平

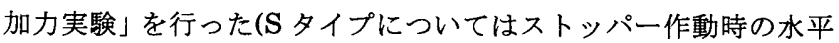
加力実験のみを示す)。隇衰材では「水平加力実験」「限界水平変 形実験」を行った。これらの実験は、図 5 に示す 2 軸試験機（最 大圧縮力: $98 \mathrm{kN}$, 最大せん断力 $49 \mathrm{kN}$, 最大ストローク $\pm 250 \mathrm{~mm}$ ) で行った。

\begin{tabular}{|c|c|c|c|}
\hline \multicolumn{4}{|c|}{ 表 1.実験計画 } \\
\hline 実験対象 & 実験種別 & 試験体 & 試験条件 \\
\hline \multirow{3}{*}{$\begin{array}{l}\text { 転 } \\
\text { か } \\
\text { り } \\
\text { 支 } \\
\text { 承 }\end{array}$} & 鉛直加力 & Nタイプ & $\begin{array}{l}\text { 単調載荷 } \\
\text { 加力速度 } 1.0 \mathrm{~mm} / \mathrm{s} \\
\end{array}$ \\
\hline & \multirow[b]{2}{*}{ 水平加力 } & Nタイプ & $\begin{array}{l}\text { 鉛直荷重 } 14.7 \mathrm{kN} \\
\text { 正負絽返し (3サイクル) } \\
\text { 加振周期 } 10 \mathrm{~s}\end{array}$ \\
\hline & & $\begin{array}{l}\text { Sタイプ } \\
\text { (ストッパー:A〜 } \\
\text { Dタイプ) }\end{array}$ & $\begin{array}{l}\text { 鉛直荷重14.7kN } \\
\text { 正鱼繰返し(3サイクル) } \\
\text { 加振周期 10s } \\
\text { ストツパー作重まで変形 }\end{array}$ \\
\hline \multirow{2}{*}{$\begin{array}{l}\text { 濐 } \\
\text { 衰 } \\
\text { 材 }\end{array}$} & 水平加力 & $\mathrm{H}=40,60,80 \mathrm{~mm}$ & $\begin{array}{l}\gamma= \pm 100 \% \cdot 4 \text { サイクル } \\
\text { 加振周期 } 10 \mathrm{~s} \\
\text { 軸变形拘束 }\end{array}$ \\
\hline & 限界水平变形 & $\mathrm{H}=40,60,80 \mathrm{~mm}$ & $\begin{array}{l}\text { 単調载荷 } \\
\text { 加力速度 } 12.6 \mathrm{~mm} / \mathrm{s} \\
\text { 軸変形拘束 }\end{array}$ \\
\hline
\end{tabular}

\section{3 実験結果}

(1)転がり支承 : 鉛直加力実験結果を図 6 に示す。最大荷重 $118 \mathrm{kN}$ まで剛性低下を生じない。なお、0.8mm 弱の残留変形が生じるが 実験では長期最大荷重の約 4 倍まで載荷したため、フランジ材に 準み(=塑性変形)が生じたためである。

水平加力実験結果を図 7 に示す。第 1 サイクル目は水平荷重が 大きいが 2 サイクル目以降は履歴ループが安定する。また、同図 中に示すように、実験で得られた荷重〜変形曲線は剛塑性形ルー プ(摩擦係数 0.008 相当)でモデル化が可能である。

$\mathrm{S}$ タイプストッパー(代表例としてストッパーC タイプ)作動時 の荷重〜変形関係は図 8 に示す通りで、 $\delta=350 \mathrm{~mm}$ 付近より急激 に反力が立ち上がり安定的にストッパー作動していることが判る。 (2)诚衰材: 水平加力実験結果(代表例として $\mathrm{H}=60 \mathrm{~mm}$ )を図 9 に示 す。第 1 サイクル目は水平荷重が大きいが 2 サイクル目以降は履 歴ループ形状が安定し、バイリニアー型のループ形状を示す。ま た、 $\gamma=100 \%$ での履歴ループの等価粘性减衰定数は $23 \%(\mathrm{H}=40 \mathrm{~mm}) 、 25 \%(\mathrm{H}=60 \mathrm{~mm}, 80 \mathrm{~mm})$ であった。

限界水平変形実験結果(代表例として高さ $60 \mathrm{~mm}$ )を図 10 に示 す。 $\delta=100 \mathrm{~mm}(\gamma=167 \%)$ 付近まではほぼ一定の剛性を示し、そ れ以降の変形ではハードニングが生じる。 $\delta=200 \mathrm{~mm}(\gamma=333 \%)$ 付近から剛性低下が始まり、 $\delta=250 \mathrm{~mm}(\gamma=417 \%)$ 付近(試験体に よりバラツキがある)から負勾配を示す。これらの結果から、限界 変形量を $170 \mathrm{~mm}(\mathrm{H}=40 \mathrm{~mm}, \gamma=425 \%) 、 240 \mathrm{~mm}(\mathrm{H}=60 \mathrm{~mm}, \gamma$ $=400 \%) 、 320 \mathrm{~mm}(\mathrm{H}=80 \mathrm{~mm}, \gamma=400 \%)$ としている。
図 4. 減衰材形状寸法及び材質

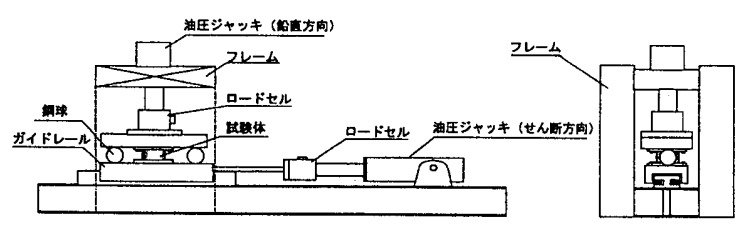

図 5. 加力装置

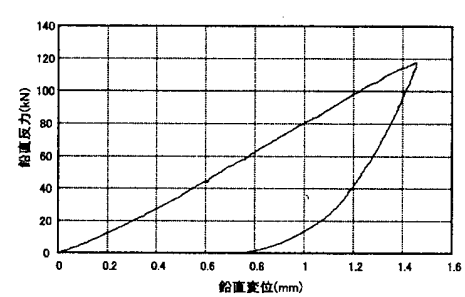

図 6. 転がり支承・鉛直加力実験結果

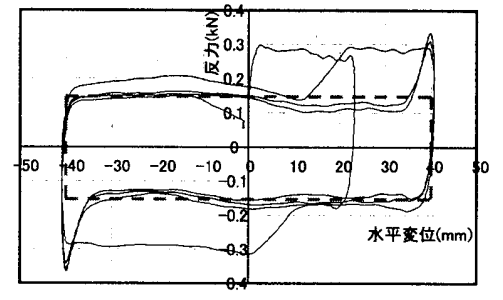

図 7. 転がり支承・水平加力実験結果 


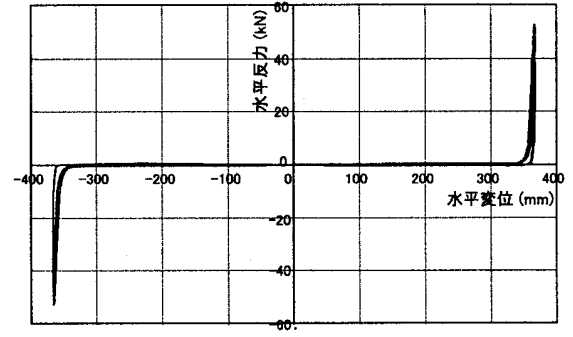

図 8. S-type ㅈッ $\Lambda^{\circ}$-作動時荷重変形関係

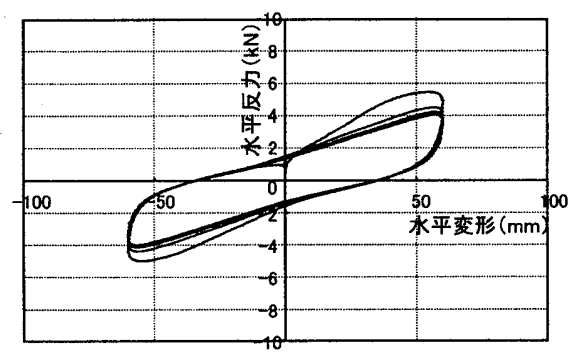

図 9. 減衰材・水平加力実験結果 $(\mathrm{H}=60 \mathrm{~mm})$

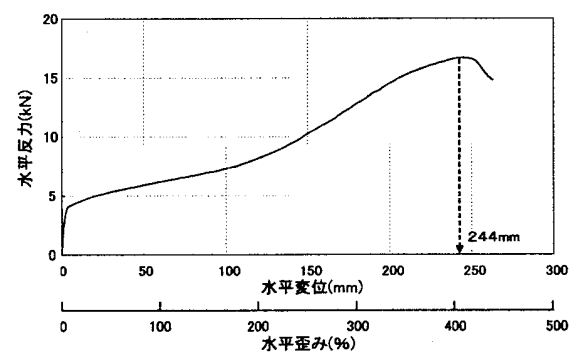

图 10. 減衰材 ·限界変形 $(\mathrm{H}=60 \mathrm{~mm})$

\section{4. 施工実験}

\section{1 実験対象建物}

図 11 に示寸標準的な戸建て住宅（延べ床面積 $136 \mathrm{~m}^{2}$ 、建築面 積 $\left.68 \mathrm{~m}^{2}\right)$ に本免震工法の適用を想定して実験を行う。図 11 の戸 建て住宅に本工法を適用した場合の免震層の形状・寸法は図 12 の通りとなる。本施工実験では、図 12 中に示す通りこの免震層 の約半分（図中の点線で囲まれた部分）を取り出して「基礎〜免 震部材据え付け〜スラブコンクリート打設〜固定金物取り外し」 までの一連の施工手順と施工精度の確認を行う。

図 13 に施工実験試験体の形状・免震部材の配置、転がり支承 の接合詳細図を示す。転がり支承は合計 18 個（N タイプ 14 個、 $\mathrm{S}$ タイプ 4 個)、減衰材は 4 組 8 個用いる。スラブは厚さ $130 \mathrm{~mm}$ で配筋は縦・横とも D13・D10 交互@200 である。また、免震層 スラブ天端は $\mathrm{GL}+705 \mathrm{~mm}$ 、基礎と免震層スラブ間のクリアラン ス（デッキプレートリブ下）は 400 mm 確保している。なお、本 施工実験では実験場屋外の既設の土間スラブを基䃈スラブに見立 てて行った。

\section{2 実験結果}

(1)施工手順 :「免震部材据え付け〜束柱コンクリート打設〜スラ ブコンクリート打設」間の一連の施工状況を写真 3 に示す。何れ の作業も当初の予定通り施工できることを確認した。

施工荷重を支持するため各転がり支承に取り付けた固定金物の 取り外しのタイミングは、建物䇋工直前を想定していた。本施工 実験では、写真 4 に示すように上部建物重量相当のコンクリート ブロックを免震層の上に載せた状態(免震層スラブ自重 $119 \mathrm{kN}$ 、 上載荷重 $126 \mathrm{kN}$ ：総重量 $245 \mathrm{kN}$ )で固定金物を取り外した。その 結果、軸力の大きな中通りでは固定金物の取り外しが困難なこと が明らかとなった。そこで、固定金物は上部建物の施工前に取り 外すこととした。写真 5 に示す通りアムスラー試験機を用いて転 がり支承に $10 \mathrm{kN}$ の鉛直荷重を作用させた状態で固定金物取り外 し実験を別途に行い、取り外しが容易であることを確認している。

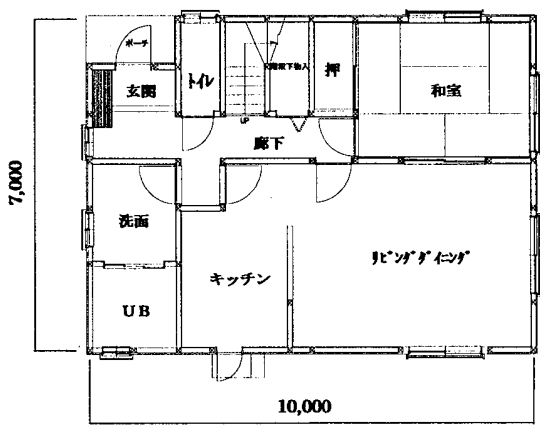

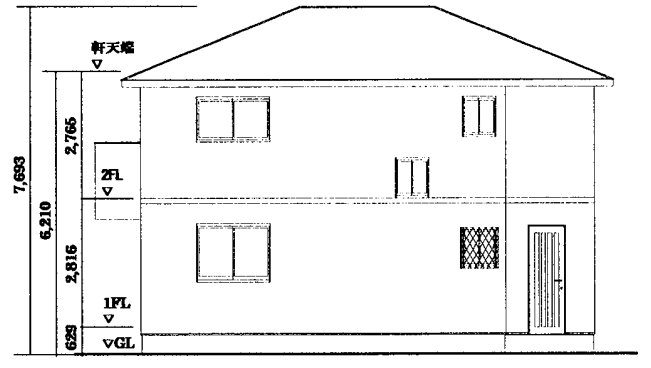

图 11. 施工実験想定建物

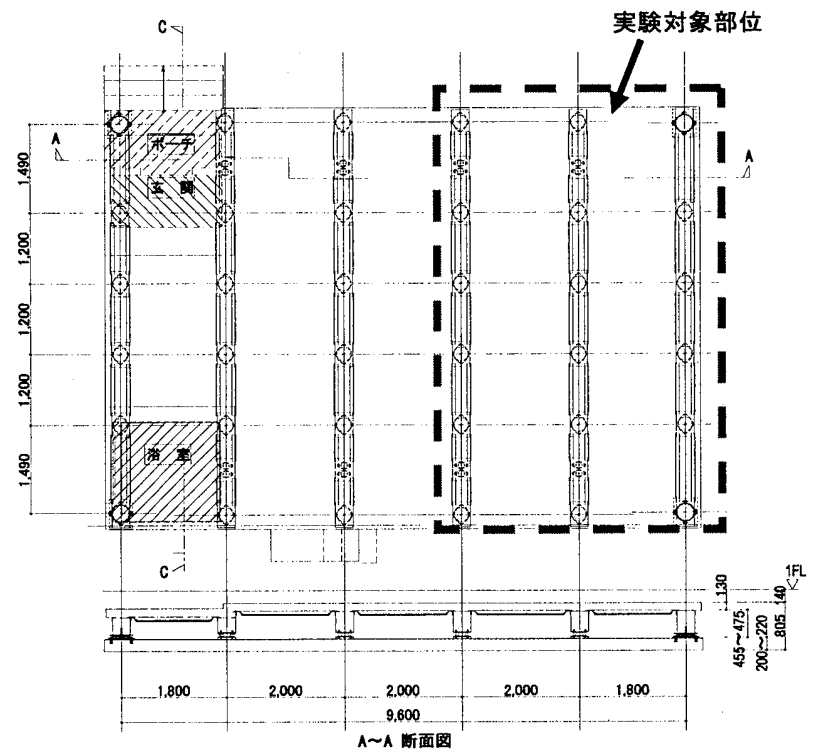

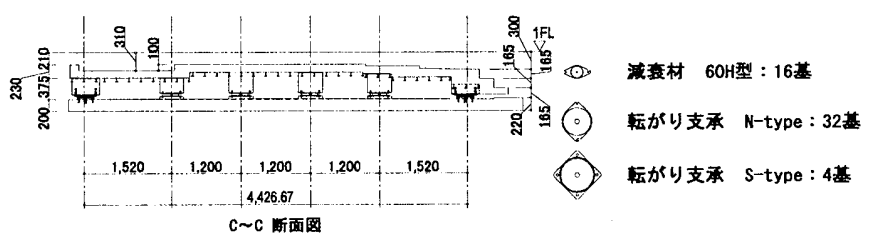

図 12. 施工実験想定免震層

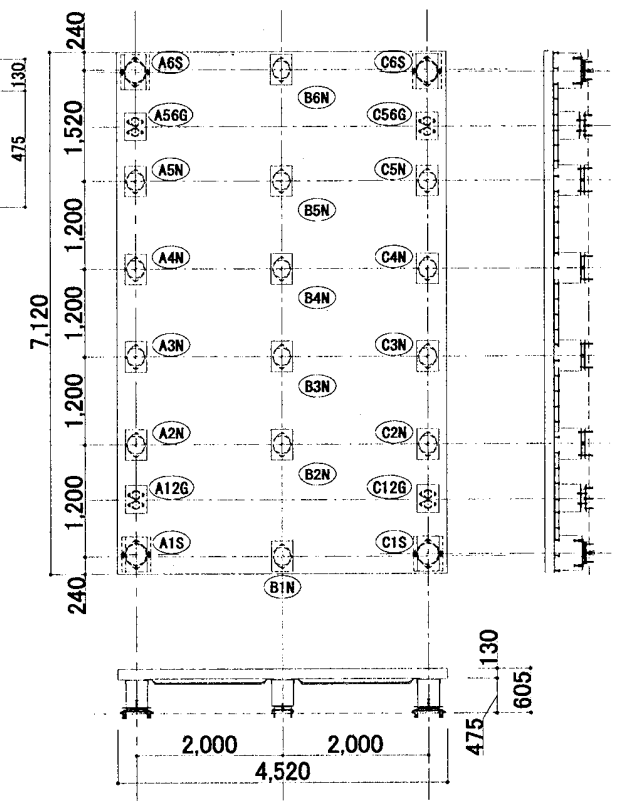

$\mathrm{N}: \mathrm{N}$ タイプ $\mathrm{S}: \mathrm{S}$ タイプ $\mathrm{G}:$ 滑衰材

図 13. 施工実験免震層 
(2)施工精度：免震部材据え付け施工精度の基鹤值と本施工実験で 得られた寒測值の比較を表 3 に示す。なお、実測値はスラブコン クリート打設後のものである(二施工荷重を固定金物で負担ざ た状態)。免震部材の相互間の距離、高さ、傾きとも基準値以内で 施土できることを確認できた

\section{5. 粠造突験}

\section{1 实験概要}

(1)試験体：施工実験で構築した免震層を対象に実験を行った。 (2)害験方法：鉛直載荷実験は写真 4に示すように免震層スラブ上 に鉄骨梁を渡しその上にコンクリートブロック(約 $5 \mathrm{kN} \times 4$ 個十 約 $10 \mathrm{kN} \times 10$ 個。重量は積載時にロードセルで測定)を順次積載し て鉛直荷重を作用させた。積載荷重は $126 \mathrm{kN}$ でスラブ自重 $119 \mathrm{kN}$ と合わせて総重量は $245 \mathrm{kN}$ である。また、支承の最大軸力(計算 值)は $27 \mathrm{kN}$ である。測定項目は、1)転がり支承の鉛直・回転変形

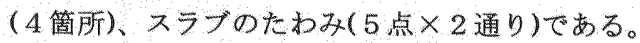

水平載荷寒験では、上記鉛淔载荷実験で免震層上に載荷した鉛 直力を作用させを状態で水平方向への加力を行5。実験は「減㐮 材なし(転がり支承の多)、「減衰材あり」の2 ケースについで行 う。加力は図 14 に示すように、実験場の土間スラブに固定した オイルジャッキにより免震層にせん断力を作用させる。加力速度 は $10 \mathrm{~mm} / \mathrm{s}$ とした。載荷パターンを図 15 に示す。隇衰材なして は. $\delta=200 \mathrm{~mm}$ まで単調載荷後、 $\delta= \pm 75 \mathrm{~mm} の$ 正負繰返し載荷、 減衰材ありでは載荷パターン $\delta= \pm 50 \mathrm{~mm}$ の正負繰返し载荷とす る(実験装置能力上減衰材ありでは $\delta= \pm 50 \mathrm{~mm}$ まで載荷となっ た)。測定項目は免震層水平変形(スラブの左右 2 点で測定)である。

\section{2 実験結果}

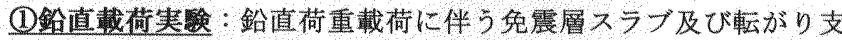
承・減衰材接合部のひび割れ発生は㒛められなかった。

束柱部分の鉛直変形 $(\delta \mathrm{v})$ 及び回転変形 $(\theta)$ を図 16 k示す。 $\delta \mathrm{v}$ 、 $\theta$ とも荷重の大きい中通り部分の変形が大きい。 $\delta \mathrm{v}<0.2 \mathrm{~mm} 、 \theta$ <1/600 rad であり十分小さな変形に収まっている。所定荷重時の スラブのたわ多を図 17 に示す。スバン中央部のたわみが最も大 きく、たわ欢量は $0.3 \mathrm{~mm}$ 以内に収まっている。

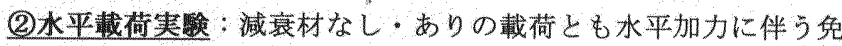
震層スフブ及び転がり支承・減衰材接合部のひび割れ発生は諮め られなかった。

減衰材なしの荷重〜変形曲線(代表例として長边力向)を図 18 に示す。第1サイクル目の荷重が大きいが、2サイクル自以降は ほほ同一履歴ループを示す。また、除荷一逆䚋への载荷途中の原 点 $(\delta=0 \mathrm{~mm})$ 付近で荷重低下 $($ ループ形状が凹形となる)部分があ る。これは写真 6 に示すよらに、鉛直力と水平力載荷に伴い上下 フランジ材に鋼球の条痕が出来て、その条痕鋼球がトレースしな がら動くためと考えられる。また、同図中に示すように、水平荷 重の実験值は部算值（重量 $\times$ 摩擦係数 0.008 ) よりも大きく、 $\delta$ $=40 \mathrm{~mm}$ (本転がり支承基淮変形)では約 1.6 倍であった。なお、実 地震では今回の実唤のように条痕上をトレースするような答変 形が生しることは稀であり、赛際は条痕を付けながらフランジ材

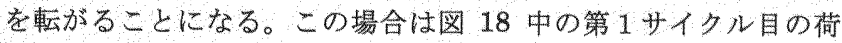
重〜変形に近いものとなるが、後に示すように免震層の復元力は
減衰材が支配的であり影響は少ないと考えられる(履歴減衰が大 きくなるので免震層の応答変位量は隇少すると考えられる)。

減衰材ありの荷重〜変形曲線を図 19 に示す。載荷回数の影響
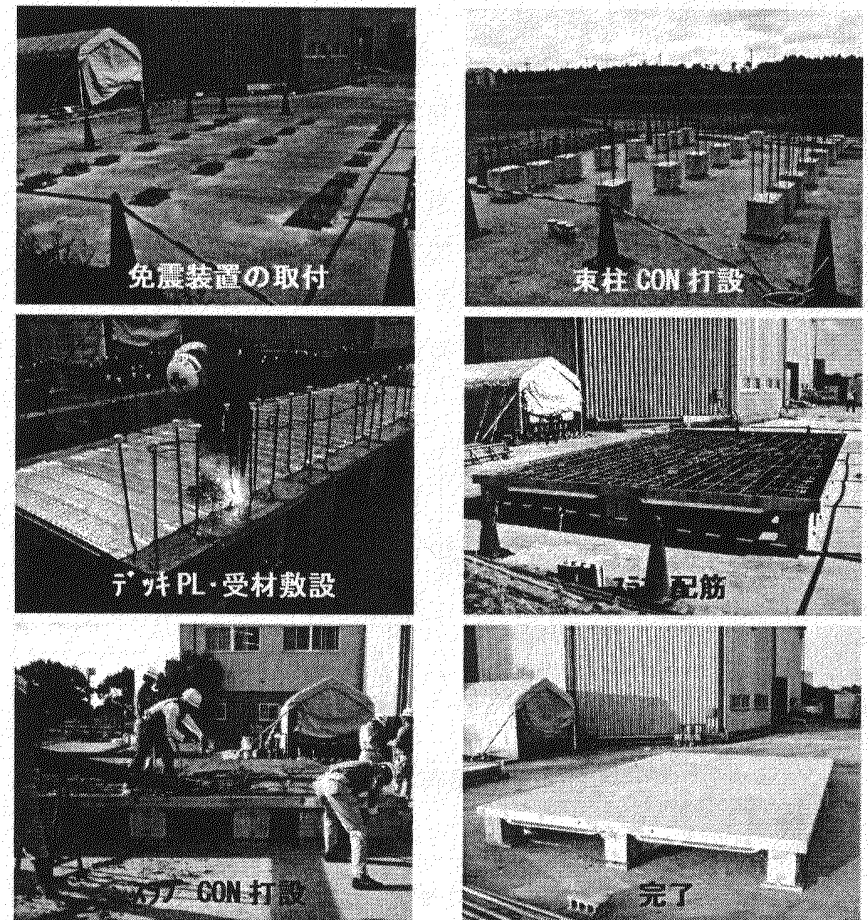

军真 3. 郝工状治
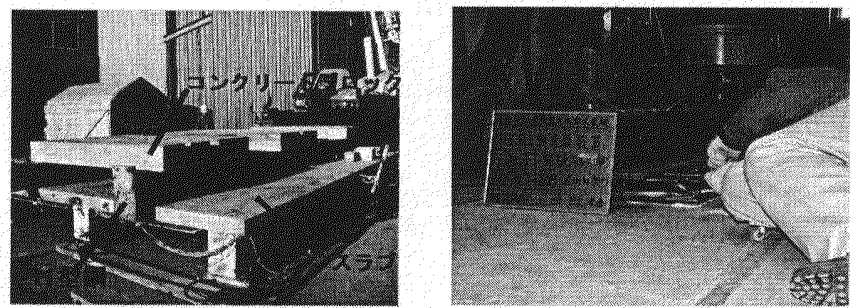

写真 4. 犍物董量上量状況

写筫 5. 固定金物取外L

表 3.施工精度 - 基準值と実測値の比較

\begin{tabular}{|c|c|c|c|c|}
\hline 管理·換面项且 & 管理-盆苴方洼 & 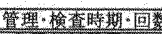 & 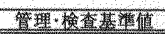 & 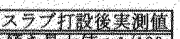 \\
\hline 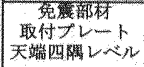 & 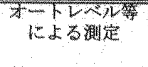 & 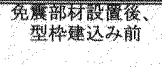 & 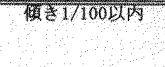 & 楯走最大蹎: 17100 \\
\hline 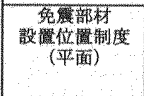 & 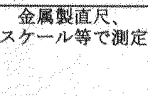 & 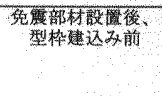 & 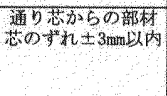 & 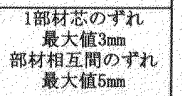 \\
\hline
\end{tabular}

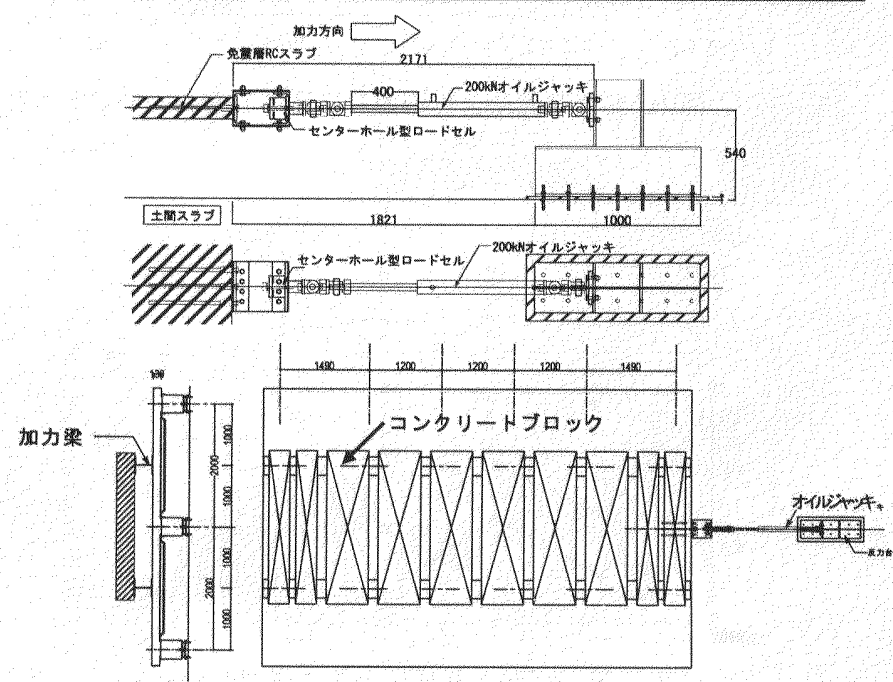

図 14. 水平戴荷实験装蝆 
が認められ、第 3 サイクル目以降でループ形状が安定する。衤歴 ループ形状は大略ではバイリニアー形の形状を示すが、隇衰材な しの場合と同様に原点付近で復歴ループがくびれる形状を示す。 これは、減㙜材なし」で述べたよらに、鋼球がフランジ材の条痕 を横切るためと考兑られる(加力装固の能力上用性が負勾配な部 分では加力は不安定になる影響も考えられる)。なお、このルーフ

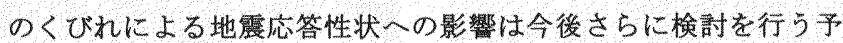
定である。また、同図中に示す通り実験値は計算値に対して若干 低い剛性を示す。これは、主に加力速度の影響であると推定され る。 $\delta=50 \mathrm{~mm}$ ての減衰材の荷重分担率は $74 \%$ あり、隇衰材が 免震屬復元力に対して支配的であることが判る。
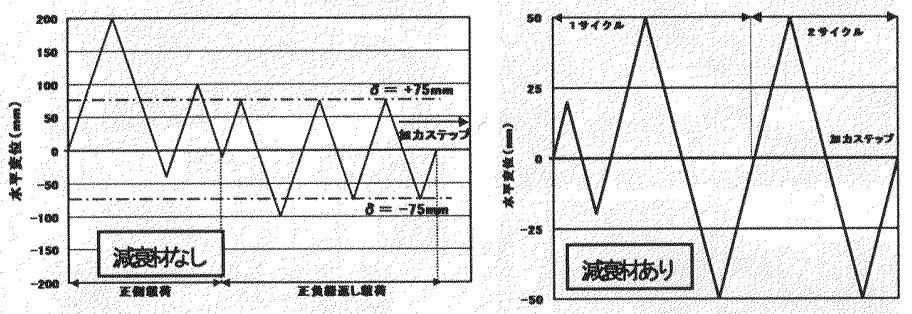

図 15. 戴荷パターン
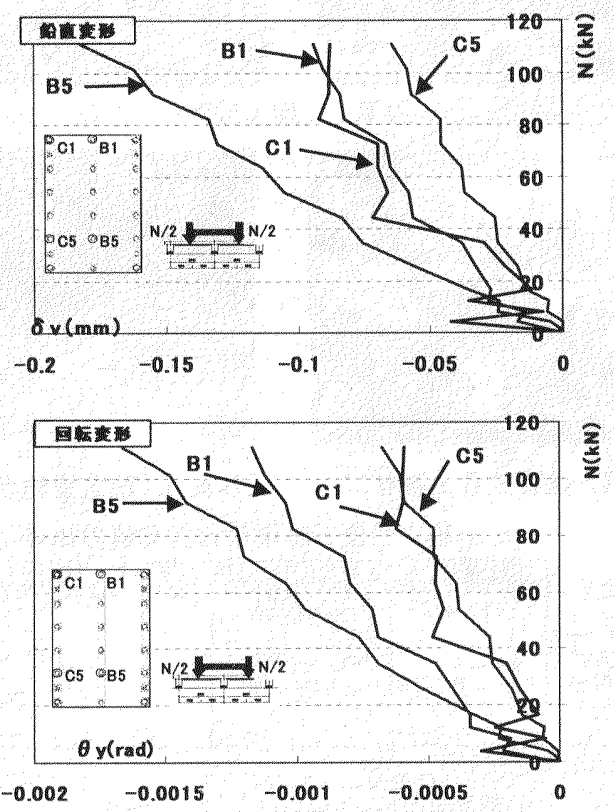

図 16. 鉛直載荷による転がり支承の変形

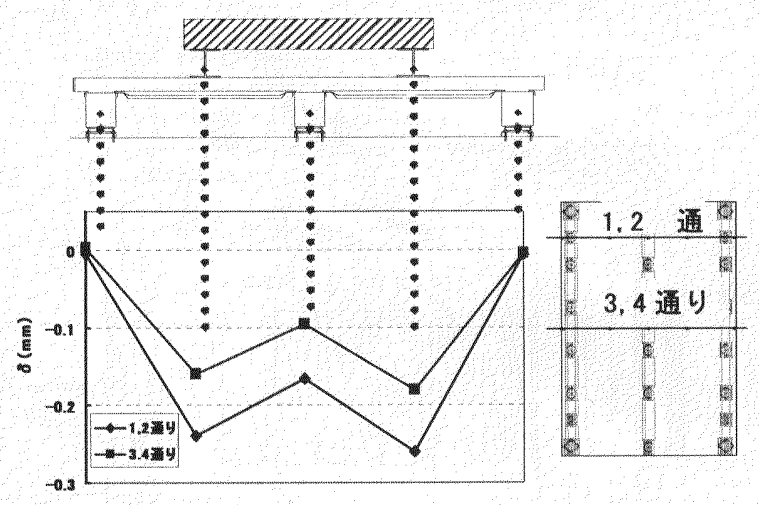

図 17. 鉛直載荷によるスラブたわみ

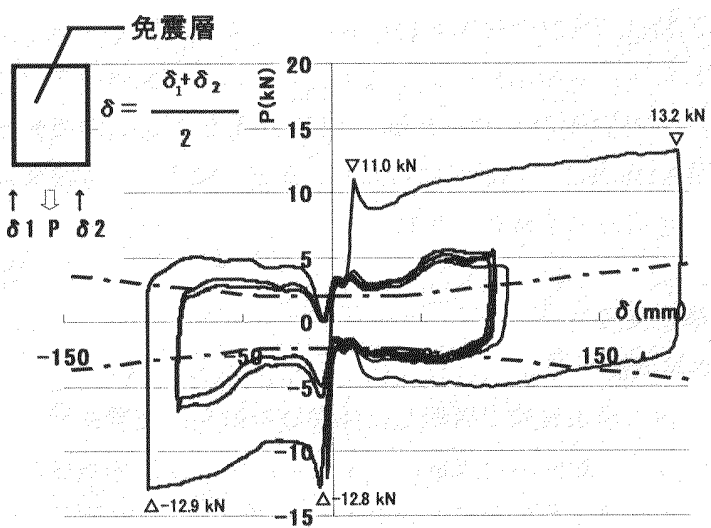

图 18. 水平载荷实験結果(隇衰村なし)

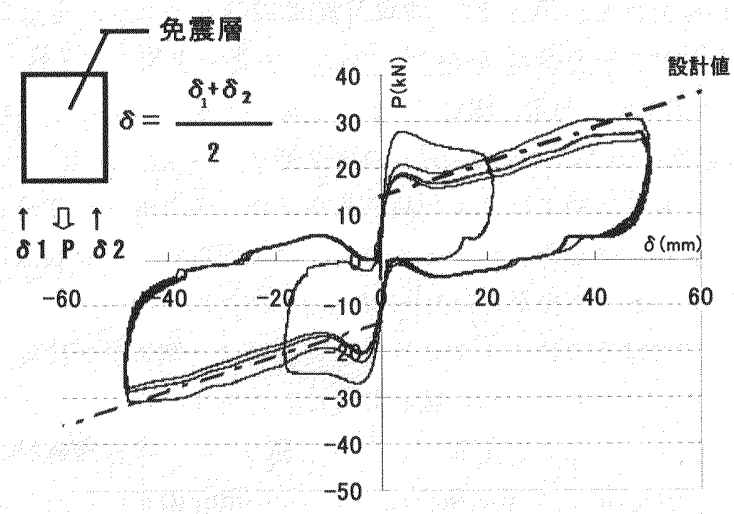

图 19. 水平戴荷突験結果（減衰材あり）

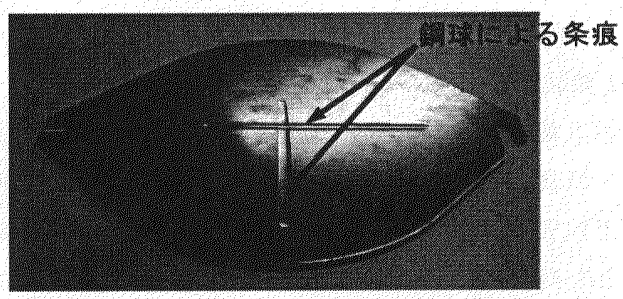

写真 6. 転がり支承フランジプレートの条痓

\section{6. まとめ}

户建て住宅への免震構造の普及を目指し、简單な構造の免震部 材を用いた免震工法を開発した。施工実験及ひ構造実験を行い下 記の点が明らかとなった。

1)転がり支承については必要な鉛直荷重支持能力 $(98 \mathrm{kN}$ 以上)が 確認できた。水平方向の荷重〜変形関倸では、単体実験は設計値 (摩擦係数 0.008) 通りであったが、免震層全体では設計値(摩擦係 数 0.008)上り約 1.6 倍の何重を示した。

2)隇衰材は安定したバイリニアーループを示し、等価隇衰定数は $23 \sim 25 \%$ でる。また、 $y=400 \%$ 以上の水平変形能力を有する。 3）基礎〜免震部材据え付け〜スラブコンクリート打設までの施I 手順は妥当であり、必要な施工精度も確保されている。

4)上部建物相当の鉛直荷重及び水平荷重に対して、免震尿スラブ、 支承・減衰材接合部にひび割れ等の損傷は発生しない。

5)フランジ村には鋼球による条痕が生しる。ここの条痕の影響によ り水平方向の履歴ループにくびれが生じる。履歴ループのくびれ が応答性状に与える影響については今後検討子定である。

[2005年 4 月20日原稿受理 2005年7月22日採用決定］ 